\title{
THE MOLECULAR WEIGHT DISTRIBUTION OF $\beta$-GLUCAN IN WORT FROM MALTS OF DIFFERENT BARLEY VARIETIES AT DIFFERENT STAGES OF MALTING
}

\author{
by \\ LARS FOLDAGER" and KIM G. JØRGENSEN ${ }^{22}$ \\ Department of Biotechnology, Carlsberg Research Laboratory, \\ Gamle Carlsberg Vej 10, DK-2500 Copenhagen Valby. \\ "present address: Department of Applied Biochemistry, The Technical University of Denmark, Building 223 , \\ DK-2800 Lyngby, Denmark. \\ 2) To whom all correspondence should be addressed.
}

\begin{abstract}
Keywords: Calcofluor, fluorescence, gel permeation chromatography, polysaccharide, viscosity
\end{abstract}

The molecular weight distributions of $\beta$-glucans from congress worts of the barley genotypes Minerva (feed barley) and Triumph (malting barley) at $0-9$ days of malting were studied by gel permeation chromatography. The amount of $\beta$-glucan was estimated using a glucose determination method and a specific fluorometric method based on an increase in the fluorescence intensity of Calcofluor when binding to high molecular weight $(>10,000)$ $\beta$-glucan. The amount of extracted $\beta$-glucan was slightly higher for Minerva than for Triumph barley at all stages of germination. The elution patterns of $\beta$-glucan in congress worts made from the two barley genotypes were similar, although the high molecular weight $\beta$-glucan analysed in worts from Triumph was decomposed during malting at a faster rate than in those from Minerva. The extracted high molecular weight $\beta$-glucans were found to have molecular weights in the range of $10^{4}-10^{6}$. The differences in the contents of high molecular weight $\beta$-glucans cannot explain all the variation in viscosities of the worts.

Abbreviations: AMS-method $=\left(\mathrm{NH}_{4}\right)_{2} \mathrm{SO}_{4}$ precipitating method; CEP-method $=$ Calcofluor/ethanol precipitating method; $\beta$-glucans $=$ Mixed linked $(1 \rightarrow 3),(1 \rightarrow 4)-\beta$-D-glucans; $\beta$-glucanase $=(1 \rightarrow 3),(1 \rightarrow 4)-\beta$-D-glucan 4-endohydrolase (EC:3.2.1.73); DMSO = Dimethylsulfoxid. (T0), (T3), (T5), (T7), (T9) and (M0), (M3), (M5), (M7), (M9) are the worts derived from the barley genotypes Triumph and Minerva maited for $0,3,5,7$ and 9 days, respectively. 


\section{INTRODUCTION}

$\beta$-glucan, the major matrix polysaccharide of barley endosperm cell walls (10), retards modification in malting (1) and affects the filtration time of wort and beer $(8,12,14,19)$. The latter effect is due to high molecular $\beta$-glucans which in solution increase the viscosity of extracts $(6$, 12).

In ungerminated barley, $\beta$-glucans are believed to be covalently bound to protein (11) forming large molecules of approximately $10^{7}$ dalton $(7,11)$. During malting and mashing the complex is degraded, resulting in $\beta$-glucans with a molecular weight of $1 \times 10^{5}-1 \times 10^{7}$ which are soluble in wort $(5,12)$. Isolated precipitates from beer has been reported to consist of $\beta$-glucan of about $7 \times 10^{4}$ in molecular weight (13).

The $\beta$-glucans in wort and beer can be measured by the AMS-method or as previously described by the use of Calcofluor (CEP-method, 15, 16). The relationship between the values determined by these methods and the viscosity of wort and beer has been investigated $(14,16,19)$, and it was shown that the $\beta$-glucan content could not fully explain the variation in viscosity.

In the present investigation, two barley varieties of different malting potential are compared in relation to differences in the molecular weight distribution of their $\beta$-glucans during malting and congress mashing. Samples of congress worts are subjected to gel permeation chromatography and fractions studied by glucose determination after acid hydrolysis. A more rapid and sensitive method based on the fluorochrome Calcofluor was developed to monitor high molecular weight $\beta$-glucan in the gel chromatography fractions. The molecular weight distribution of $\beta$-glucan in the samples are related to conventional malt analysis i.e. malt modification, moisture content, extract content, viscosity, and $\beta$-glucan content of malts and worts.

\section{MATERIALS AND METHODS}

\subsection{Plant material}

A good quality malting barley (Triumph) and a poor malting barley (Minerva) were supplied by STEEN AASTRUP, Department of Brewing Chemistry, Carlsberg Research Laboratory.
Quadruplicate samples of $200 \mathrm{~g}$ of each barley variety were steeped at $15{ }^{\circ} \mathrm{C}$ for $3 \times 8$ hours, interrupted by $2 \times 16$ hours air rests, followed by malting at $15{ }^{\circ} \mathrm{C}$ in rotating stainless steel net drums for 16 hours at $100 \%$ humidity. Samples were withdrawn after 0,2, 4 and 6 days of germination and kilned. The kilning programme used was $0-16$ hours at $50^{\circ} \mathrm{C}$ and $16-21$ hours at $80{ }^{\circ} \mathrm{C}$ in a heat cabinet with recycled air. Total $\beta$-glucan of the barley and malt samples were measured enzymatically as described by ANDERSON et al. (4). Protein was determined by the Kjeldahl analysis and malt modification and homogeneity were measured after AASTRUP and ERDAL (2), using the visual Calcofluor method.

\subsection{Malt and wort analyses}

Worts derived from malt and barley were made at the Central Laboratory of the Carlsberg Brewery by J.C. LORENZEN. The congress mashing and the standard malt analyses were performed according to the Analysis Committee of the European Brewing Convention (3). Viscosity of wort was measured at $20{ }^{\circ} \mathrm{C}$ with a Contraves Low Shear 100 Viscometer (Contraves A. G., Zurich, Switzerland).

The method of PreECE and MACKenzie (18) was used as modified by ERDAL and GJERTSEN (9) for measuring soluble $\beta$-glucan. The $\beta$-glucans were precipitated by $30 \mathrm{~g}\left(\mathrm{NH}_{4}\right)_{2} \mathrm{SO}_{4}$ (AMS) per $100 \mathrm{ml}$ wort at $0{ }^{\circ} \mathrm{C}$ for 1 hour, centrifuged and washed twice with $20 \%$ ethanol. The precipitate was dissolved and hydrolysed in $1 \mathrm{~N} \mathrm{H}_{2} \mathrm{SO}_{4}$ by boiling for $15 \mathrm{~min}$ and the amount of reducing carbohydrate in the solution was measured with phenol and sulphuric acid (9). Absorption was read at $490 \mathrm{~nm}$ using glucose as standard.

$\beta$-glucan in the worts were further determinated with Calcofluor (CEP-method, 16) by mixing $0.5 \mathrm{ml}$ wort $\left(20^{\circ} \mathrm{C}\right)$ with an aliquot of $0.5 \mathrm{ml}$ of $1 \mathrm{~g} \cdot \mathrm{L}^{-1}$ Calcofluor (Polyscience Inc., Warrington, PA, USA) in $40 \%(\mathrm{v} / \mathrm{v})$ aqueous DMSO. The mixture was kept in a waterbath at $20^{\circ} \mathrm{C}$ for $15 \mathrm{~min}$ and the Calcofluor $\beta$-glucan complex precipitated with $4 \mathrm{ml} 96 \%$ ethanol, centrifuged and washed twice with $5 \mathrm{ml}$ of $80 \%$ ethanol. The precipitate was redissolved in 5 $\mathrm{ml}$ of $0.5 \mathrm{M}$-Glycine $/ \mathrm{NaOH}$ buffer, $\mathrm{pH}=10.0$, 
and fluorescence read in a spectrofluorometer (Jasco model FP 550, Japan spectroscopic Co. Ltd.). Excitation and emission wavelengths were 363 and $425 \mathrm{~nm}$, respectively.

\subsection{Preparation of samples for gel permeation chromatography}

Prior to chromatography of wort samples, the content of low molecular substances and residual $\alpha$-glucans was reduced as follows: $50 \mathrm{ml}$ of wort was mixed with $10 \mathrm{mg}$ of pancreatic $\alpha$-amylase (Fluka, A.G. Buchs, S.G., Switzerland), specific activity of $25 \mathrm{U} \cdot \mathrm{mg}^{-1}$, free of $\beta$-glucanase activity. The mixture was incubated at $50{ }^{\circ} \mathrm{C}$ for 24 hours followed by dialysis for 48 hours in standard cellulose tubing (cut off for globular proteins: 10,000-12,000 dalton). After dialysis, $0.1 \mathrm{~g} \cdot \mathrm{L}^{-1}$ Thimerosal (Sodium ethylmercurithiosalicylat) was added to prevent bacterial growth. Samples were kept at $5^{\circ} \mathrm{C}$ until use.

In order to evaluate the specificity of the $\beta$-glucan determinations (section 2.4), a sample of Congress wort (M3), was incubated with a purified $\beta$-glucanase after treatment with $\alpha$ amylase and dialysis. $\beta$-glucanase was supplied by B.S. ENEVOLDSEN and K. ERDAL, Department of Brewing Chemistry, Carlsberg Research Laboratory. The enzyme had a $\beta$-glucanase activity of $4.7 \mathrm{U} \cdot \mathrm{ml}^{-1}$ at $\mathrm{pH}=6.5$ and $10 \mathrm{ml}$ of the pretreated wort was mixed with $300 \mu \mathrm{l}$ of the enzyme and incubated at $40{ }^{\circ} \mathrm{C}$ for 24 hours.

To determine the specificity of Calcofluor binding to $\beta$-glucan of different molecular weight, a solution containing pure $\beta$-glucan of approximate molecular weights from 2000 to 300,000 was made. $0.3 \mathrm{~g}$ of barley $\beta$-glucan from Biocon (Biochemicals Ltd. Kilnagleary, Carrigatine Co., Cork, Ireland, bach no.: 912110) was dissolved in $95 \mathrm{ml}$ of water. The solution was heated to boiling and $5 \mathrm{ml} 1 \mathrm{M}-\mathrm{H}_{2} \mathrm{SO}_{4}$ was added. After $0,5,10,30,45,60,90$ and $120 \mathrm{~min}$ at boiling $10 \mathrm{ml}$ aliquots were removed, neutralized with $\mathrm{Ba}(\mathrm{OH})_{2}$ and centrifuged. All supernatants were mixed and a subsample used for gel permeation chromatography.

\subsection{Gel permeation chromatography and analyses of fractions}

One ml samples (section 2.3) were fractionated on a $16 \times 633 \mathrm{~mm}$ column of Sephacryl S-300 Superfine (Pharmacia Fine Chemicals, Uppsala, Sweden) and on a $16 \times 640 \mathrm{~mm}$ column of Biogel A-15m (200-400 mesh, BioRad Laboratories, Richmond, USA). The columns were eluted with $0.1 \mathrm{M}-\mathrm{NaCl}$ containing $5 \%$ DMSO and $0.005 \%$ Thimerosal at a flow rate of 7.5 $\mathrm{ml} \cdot \mathrm{h}^{-1}$ for the Sephacryl S-300 and $6.0 \mathrm{ml} \cdot \mathrm{h}^{-1}$ for the Biogel A- $15 \mathrm{~m}$ columns; fractions of 2.56 and $3.00 \mathrm{ml}$ were collected after elution with 46 and $36 \mathrm{ml}$ buffer, respectively. The columns were calibrated using standard $\alpha$-dextrins T10, T40, T70, T110, T250 and T500 (Pharmacia Fine Chemicals).

The amount of glucans in fractions was determined by measuring glucose after acid hydrolysis. $1.0 \mathrm{ml}$ of each fraction was mixed with $500 \mu \mathrm{l} 1.5 \mathrm{~N} \mathrm{H}_{2} \mathrm{SO}_{4}$ and boiled for one hour. The sample was cooled to room temperature, neutralized with $375 \mu \mathrm{l} 4 \mathrm{~N} \mathrm{NaOH}$ and glucose measured enzymatically using the GOD-Perid method (Boehringer Mannheim $\mathrm{GmbH}$, West Germany). Absorbance was read at $436 \mathrm{~nm}$. Because the method is sensitive to Thimerosal, glucose standards were in elution buffer.

The ability of Calcofluor to bind $\beta$-glucan (21), causing an increase in the emission intensity of Calcofluor, was also used to determine the $\beta$-glucan content of gel chromatography fractions. $0.5 \mathrm{ml}$ of each fraction was mixed with $2.5 \mathrm{ml} 0.001 \%$ Calcofluor solubilized in $0.2 \mathrm{M}-$ Glycine $/ \mathrm{NaOH}$ buffer, $\mathrm{pH}=10.0$ and fluorescence intensity measured. To obtain a maximum response between the blank (pure eluent + Calcofluor solution) and the samples, a $0.001 \%$ Calcofluor solution was used for low to moderate concentration of $\beta$-glucan $(0-50$ $\left.\mu \mathrm{g} \cdot \mathrm{ml}^{-1}\right)$. For concentrations in the range from 50 to $100 \mu \mathrm{g} \cdot \mathrm{ml}^{-1}$ the Calcofluor concentration was raised to $0.002 \%$ and for higher concentrations the samples were diluted. The Calcofluor solutions were made fresh from a $0.1 \%$ stock solution. The excitation wavelength was $350 \mathrm{~nm}$ ( $3 \mathrm{~nm}$ slit) with the light intensity lowered by placing a neutral grey filter (NG 11,2 mm from Schott, Mannheim, West Germany). The emission wavelength was $425 \mathrm{~nm}$ (5 nm slit). 
Table I.

Analyses of malt and wort samples.

\begin{tabular}{|c|c|c|c|c|c|c|c|c|c|}
\hline \multicolumn{6}{|l|}{ Malt } & \multirow{2}{*}{$\begin{array}{l}\text { Wort } \\
\text { Wort } \\
\text { extract } \\
\left({ }^{\circ} \mathrm{P}\right)\end{array}$} & \multirow[b]{2}{*}{$\begin{array}{l}\text { Visco- } \\
\text { sity } \\
\text { (cP) }\end{array}$} & \multicolumn{2}{|c|}{$\beta$-glucan ${ }^{\mathrm{b}}$} \\
\hline $\begin{array}{l}\text { Malting } \\
\text { time (days) }\end{array}$ & $\begin{array}{l}\text { Total }^{\mathrm{b}} \\
\beta \text {-glu- } \\
\text { can(\%) }\end{array}$ & $\begin{array}{l}\text { Moisture } \\
\text { content } \\
(\%)\end{array}$ & $\begin{array}{l}\text { Malt } \\
\text { modifi- } \\
\text { cation(\%) }\end{array}$ & $\begin{array}{l}\text { Homo- } \\
\text { genei- } \\
\text { ty(\%) }\end{array}$ & $\begin{array}{l}\text { Extract } \\
\text { content fine } \\
\text { grind }\left({ }^{\circ} \mathrm{P}\right)\end{array}$ & & & $\begin{array}{l}\quad \beta \text {-gluc } \\
(\mathrm{AMS}) \\
\left(\mathrm{mg} \cdot \mathrm{L}^{-1}\right)\end{array}$ & $\begin{array}{l}\mathrm{n}^{\mathrm{b}} \\
(\mathrm{CEP}) \\
(\mathrm{mV})^{\mathrm{c}}\end{array}$ \\
\hline \multicolumn{10}{|c|}{ TRIUMPH (T) } \\
\hline 0 & 3.90 & 13.2 & - & - & - & 5.59 & 2.96 & - & - \\
\hline $3^{\mathrm{a}}$ & 2.92 & 47.5 & 19 & 50 & $\begin{array}{c}63.3 \\
(69.9)\end{array}$ & $\begin{array}{c}7.90 \\
(7.95)\end{array}$ & 2.58 & $\begin{array}{c}2044 \\
(1594)\end{array}$ & 2580 \\
\hline 5 & 1.55 & 44.3 & 70 & 59 & 75.3 & 8.54 & 1.75 & 284 & 473 \\
\hline 7 & 0.87 & 41.8 & 93 & 63 & 75.6 & 8.56 & 1.69 & 37 & 169 \\
\hline 9 & 0.58 & 39.5 & 99 & 94 & 75.1 & 8.51 & 1.69 & 17 & 118 \\
\hline \multicolumn{10}{|c|}{ MINERVA (M) } \\
\hline 0 & 5.20 & 13.2 & - & - & - & 3.23 & 3.30 & - & - \\
\hline $3^{\mathrm{a}}$ & 5.40 & 48.0 & 17 & 59 & $\begin{array}{c}67.2 \\
(68.8)\end{array}$ & $\begin{array}{c}7.68 \\
(7.78)\end{array}$ & 4.96 & $\begin{array}{c}3590 \\
(3060)\end{array}$ & 4350 \\
\hline 5 & 2.55 & 44.8 & 62 & 76 & 72.8 & 8.27 & 2.24 & 954 & 1060 \\
\hline 7 & 2.20 & 42.4 & 88 & 49 & 72.3 & 8.22 & 1.93 & 103 & 294 \\
\hline 9 & 1.90 & 39.3 & 96 & 79 & 72.7 & 8.27 & 1.82 & 20 & 151 \\
\hline
\end{tabular}

a: Two sets of wort samples derived of barley germinated for 3 days have been made using the same green malt, the analyses for the latter are shown in parantheses, and this set was used for the fluorescence analyses only (section 3.4). b: Mean of duplicate measurements. c: Output voltage from fluorometer.

\section{RESULTS}

\subsection{Analyses of malt and worts}

The results obtained for malts and worts derived from Triumph and Minerva are outlined in Table I. The rate of modification was found to be slightly lower in Minerva than in Triumph. The higher initial content of $\beta$-glucan present in Minerva compared to Triumph (about $1.3 \%$ ) was retained during malting (column 2). Significant amounts of $\beta$-glucan could be determined even in overmodified malts with the enzymatic method $(0.58 \%$ and $1.90 \%$ for Triumph and Minerva malts, respectively).

The extract contents, of the worts (column 6) were low for the ungerminated barleys, while worts derived from malts with a modification degree of $60 \%$ or more resulted in almost equal extract contents for the Triumph samples and for the Minerva ones.

Viscosity measurements of the congress worts (column 8) were found to cover a wide range from $1.69 \mathrm{cP}$ to $4.96 \mathrm{cP}$. Worts derived from samples of Minerva malted at different degrees were found to be significantly higher in viscosity than worts from similary modified samples of Triumph. The correlation coefficients between the logarithm of viscosity and $\beta$-glucan estimated with the AMS-method and the CEP-method of the 8 wort samples (3-9 days of malting) were $R=0.976$ and $R=0.973$. There are, however, important discrepancies which indicate that the viscosity of worts cannot solely be accounted for by their $\beta$-glucan contents. For instance, the $\beta$-glucan content of (M9) is lower than that of (T5) (20 mg $\cdot \mathrm{L}^{-1}$ compared to 284 $\left.\mathrm{mg} \cdot \mathrm{L}^{-1}\right)$ while the wort viscosity of (M9) is higher than that of (T5) $(1.82 \mathrm{cP}$ and $1.75 \mathrm{cP}$, respectively).

\subsection{Gel permeation chromatography of wort on Sephacryl S-300 column, monitored by determination of the total glucan content}

$\beta$-glucans in worts were fractionated by chromatography on Sephacryl S-300 and the total glucan content of the fractions measured by 
glucose analysis (Figures $1 \mathrm{a}$ and $1 \mathrm{~b}$ ). By this method the $\beta$-glucan from all worts could roughly be classified into three groups according to molecular weight distribution: 1) a high molecular weight fraction ( $\mathrm{HMW}$ ) containing $\beta$ glucan of approximately $\left.10^{5}, 2\right)$ a low molecular weight fraction (LMW) containing $\beta$-glucan of approx. 4-6 $\times 10^{3}$ and finally, 3) a fraction consisting of oligosaccharides and sugars with molecular weight less than $2 \times 10^{3}$.

The wort derived from ungerminated Triumph (T0) was found to consist of a HMW fraction and a LMW fraction of approximately same quantity. The wort derived from 3 days germinated Triumph (T3) showed a 50\% decrease in the HMW fraction and $300 \%$ increase in the LMW fraction compared to (T0). After 5 days of germination (T5) the HMW fraction was almost decomposed and the LMW fraction was significantly reduced. The elution patterns of samples of Triumph malted for longer periods were almost identical. In these worts the HMW fractions were completely degraded and the LMW fractions reduced to a shoulder in the peak of oligosaccharides eluted near the total volume of the column.

The elution and decomposition pattern of $\beta$-glucans in worts derived from Minerva were much the same as those from Triumph. However, there were two important differences between the varieties. First the Minerva barley extract (M0) contained only HMW glucans. Second, to ensure complete HMW degradation after congress mashing, Minerva had to be germinated for $7-9$ days, while Triumph only required about 5 days of germination.

Analyses of the $\beta$-glucanase treated wort (M3) by the glucose determination method (section 2.4) indicated, that the HMW fraction and parts of the LMW fraction consisted of $\beta$-glucan sensitive to $\beta$-glucanase (Figure 2).

\section{3. $\beta$-glucan determination by the developed Calcofluor method}

The increase in the emission intensity of $0.001 \%$ Calcofluor in presence of increased amounts of barley $\beta$-glucan showed a linear relationship (Figure 3). A linear regression analysis between the amount of $\beta$-glucan as spe- cified in Figure 3 and the increase in fluorescence intensity at maximum emission provided a correlation coefficient $\mathrm{R}=\mathbf{0 . 9 9 7}$.

This method for estimating $\beta$-glucan is convenient and sensitive. The sensitivity could be further increased; by use of a $0.0005 \%$ Calcofluor solution it was posible, without notable fading of the fluorescence, to detect as little as $0.5 \mathrm{mg} \cdot \mathrm{L}^{-1}$ of $\beta$-glucan in a standard solution.

\subsection{Gel permeation chromatography of wort samples studied by use of Calcofluor}

Fractions of wort samples (Table l) separated on the Sephacryl S 300 column were analyzed by the Calcofluor method (section 2.4). The results showed that only $\beta$-glucan with a molecular weight above approximately $1 \times 10^{4}$ gave a fluorescence response (Figures $1 \mathrm{c}$ and $\mathrm{Id}$ ). The response of fractions of higher molecular weight correlated well with values from the glucose assay (Figures $1 \mathrm{a}$ and $\mathrm{lb}$ ). This approximate cut off value was verified by analyzing $\beta$-glucan fractions with known molecular weight compositions. A preparation of partially degraded barley $\beta$-glucan (section 2.3) was chromatographed on Sephacryl S-300 and glucose in the fractions measured after acid hydrolysis. The preparation contained $\beta$-glucan in the range of $2 \times 10^{3}$ to $2.5 \times 10^{5}$ dalton. These fractions were also studied with the fluorescence method and a ratio between increase in fluorescence intensity and the glucose determination was calculated (Figure 4). Only $\beta$-glucans larger than $1 \times 10^{4}$ dalton were found to induce an increase in fluorescence intensity of the Calcofluor molecule, and the quantum yield of the fluorescence complex reached a constant value when Calcofluor was bound to $\beta$-glucan molecules larger than about $8 \times 10^{4}$ dalton. At all stages of malt modification, a higher fluorescence response (more HMW $\beta$-glucan) was present in worts derived from Minerva malts than from Triumph malts. After 7 days of germination the Triumph worts (T7), (T9) did not contain any HMW $\beta$-glucan, while minor amounts of HMW $\beta$-glucans were found in Minerva worts even after 9 days germination (M9).

It should be noted that no fractions of $\beta$-glucanase treated wort showed any increase in fluorescence intensity, confirming that Calcofluor 
L. Foldager \& K.G. Jørgensen: Molecular weight distribution of $\beta$-glucan.
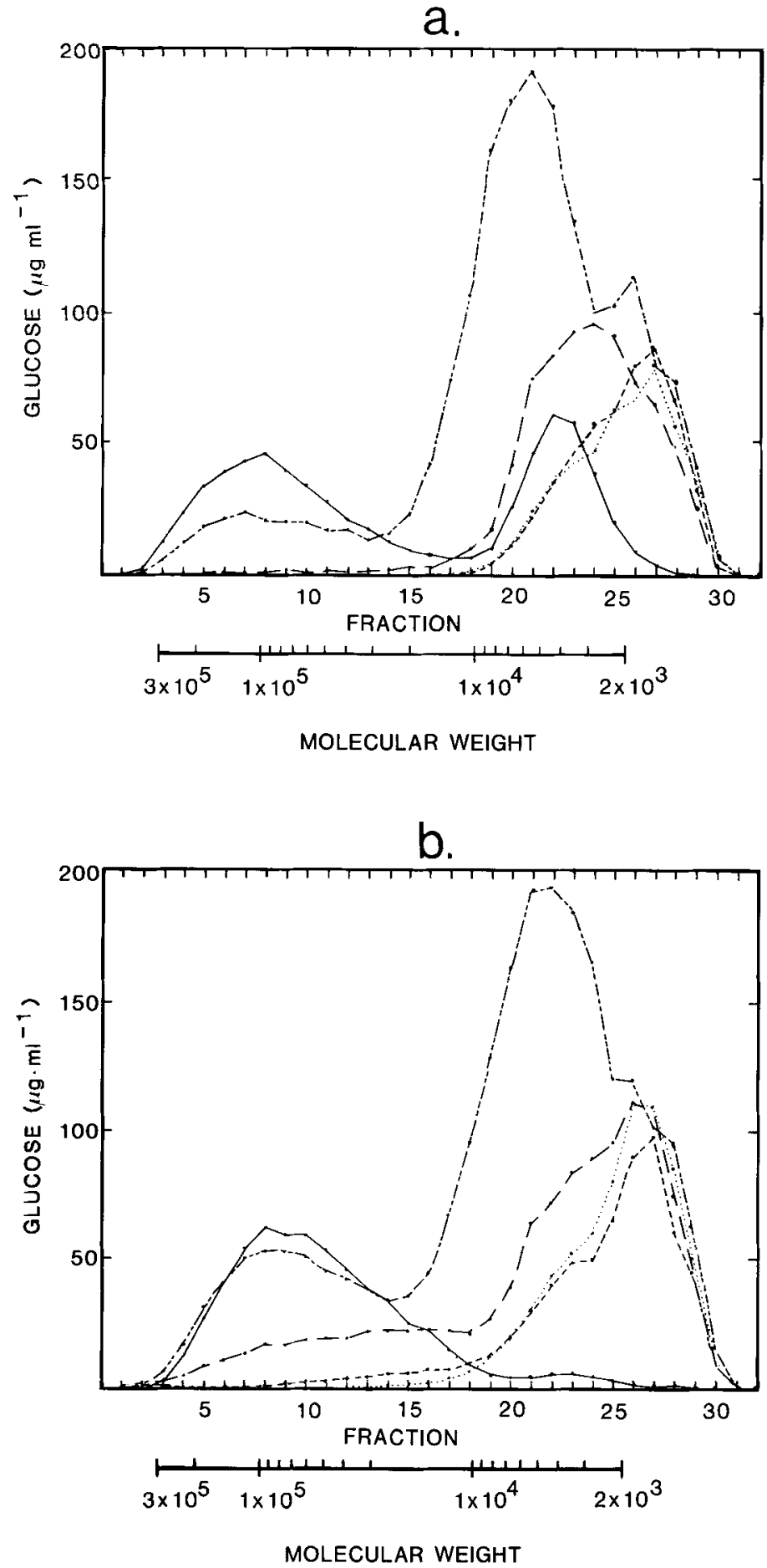

Figure 1a-1d. Molecular weight distribution of $\beta$-glucan in congress wort extracts in relation to germination time. Gel permeation chromatography was performed by Sephacryl S-300.

Germination time of barley samples: $(-)=$ ungerminated barley, $(-\cdots \cdots-)=3$ days, $(---)=5$ days, $(---)=7$ days, $(\cdots \cdots)=9$ days. Figures a \& $\mathrm{c}$ : Worts made of the barley genotype Triumph. 
L. FoldaGER \& K.G. JøRGENSEN: Molecular weight distribution of $\beta$-glucan.

C.
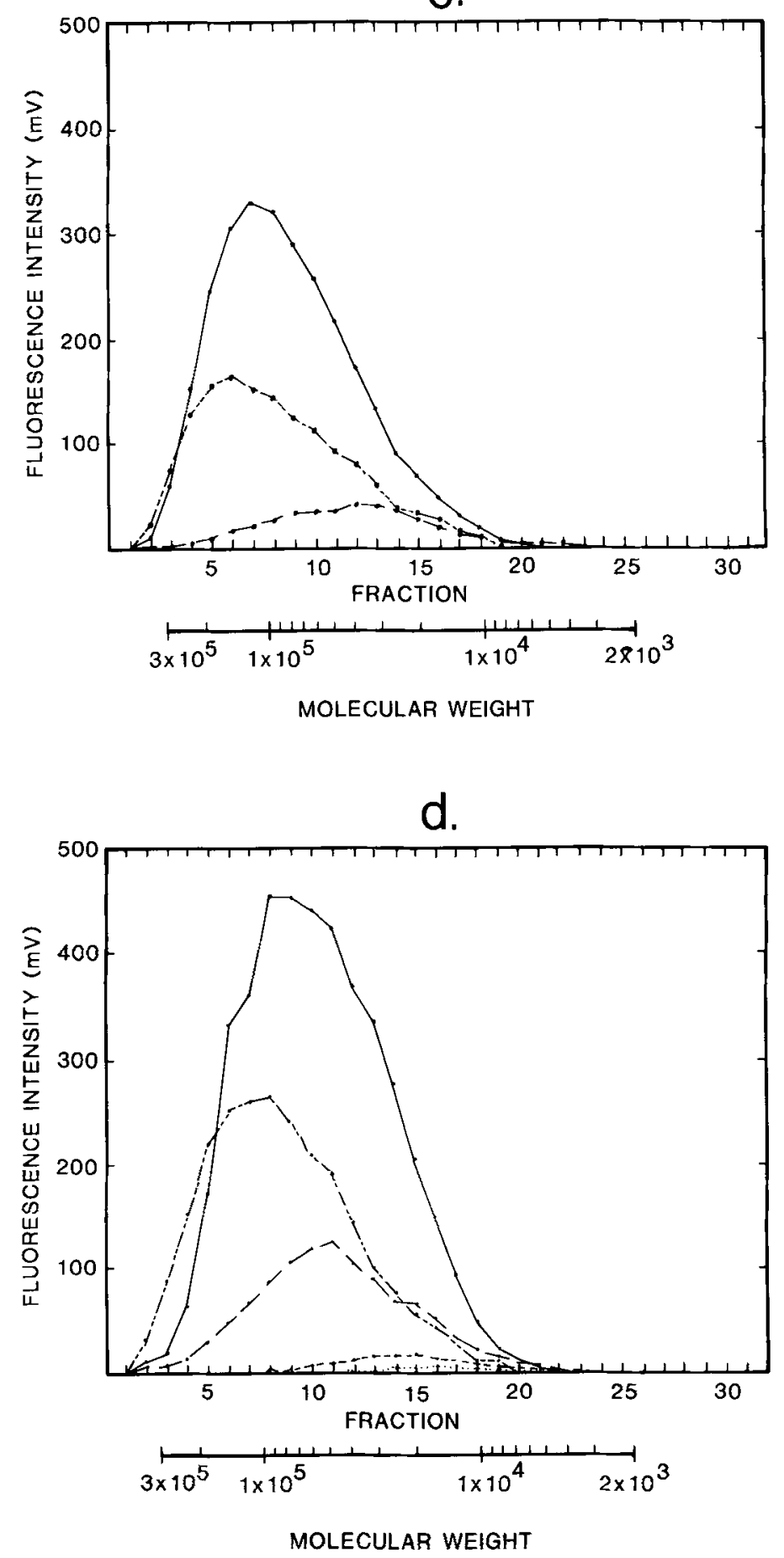

Figures b \& d: Worts made of the barley genotype Minerva.

Figures a $\&$ b: Studied by glucose determination after acid hydrolysis.

Figures $c \&$ d: Studied by the Calcofluor method. 
L. Foldager \& K.G. Jørgensen: Molecular weight distribution of $\beta$-glucan.

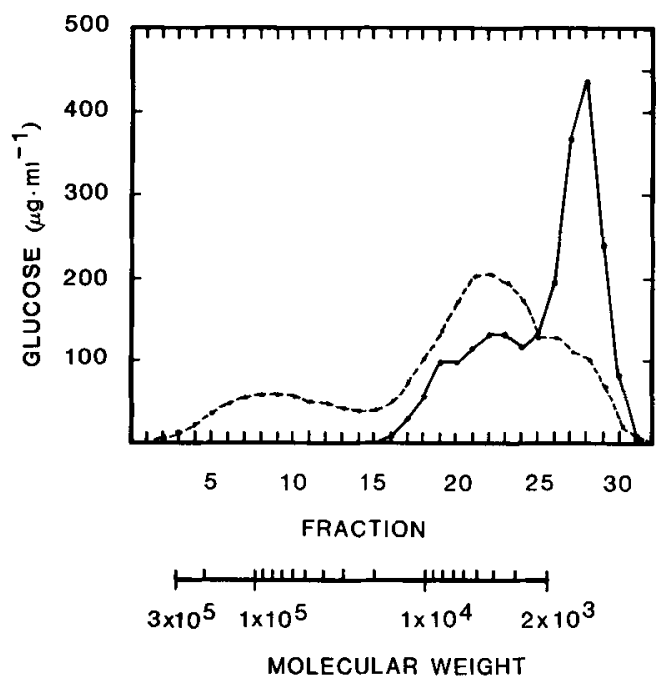

Figure 2. Effect of $\beta$-glucanase treatment on wort (M3). Gel permeation chromatography of: (----) = untreated wort, $(-)=\beta$-glucanase treated wort. Chromatography was performed by Sephacryl S-300 and fractions examinated by the glucose method.

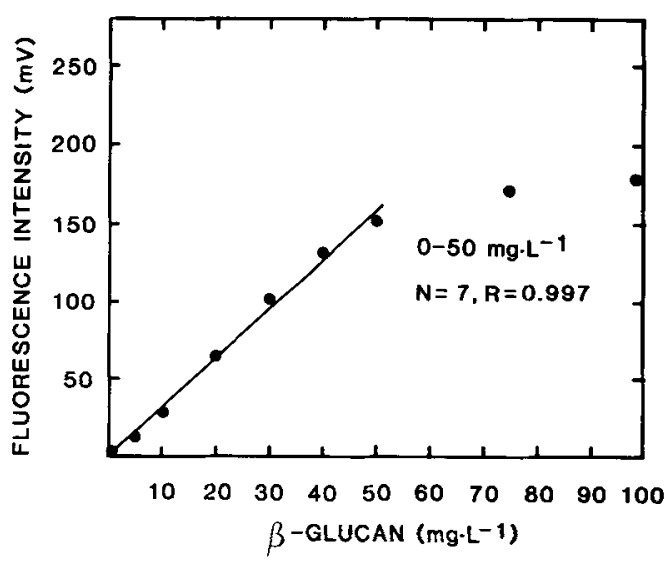

Figure 3. The relationship between the increase in fluorescence intensity and the concentration of $\beta$-glucan. $2.5 \mathrm{ml}$ of $0.001 \%$ Calcofluor in Glycine $/ \mathrm{NaOH}$ buffer, $\mathrm{pH}=10.0$, was mixed with $0.5 \mathrm{ml}$ samples of barley $\beta$-glucan dissolved in elution buffer.

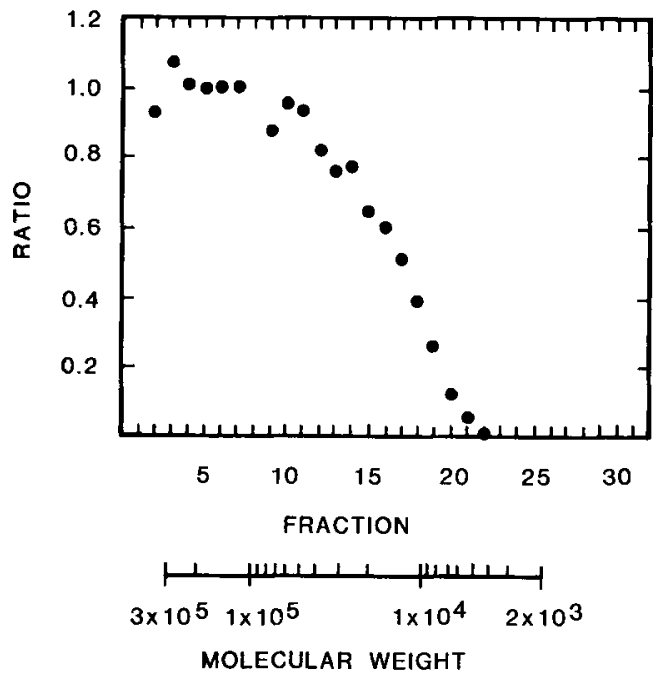

Figure 4. The specificity of the Calcoflour fluorescence method.

Ratio $=\frac{\text { increase in fluorescence intensity }}{\text { amount of glucose }} \times \mathrm{N}$

$\mathrm{N}=$ normination factor, so ratio is between 0 and 1 .

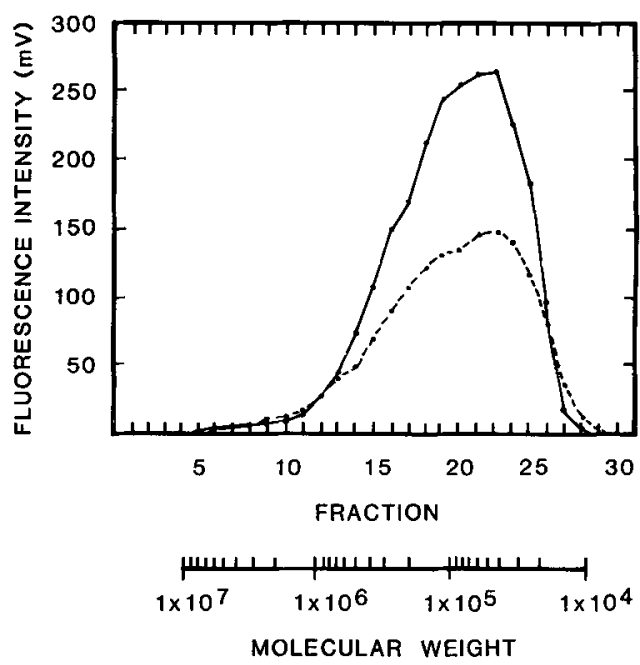

Figure 5. Gel permeation chromatography of congress worts on a Biogel A $15 \mathrm{~m}$ column, $\beta$-glucan detected by the Calcofluor method. Worts made of barley genotype Triumph (----) and barley genotype Minerva (- - ) germinated for 3 days. 
estimates only high molecular weight $\beta$-glucans.

Very high molecular weight $\beta$-glucans were examined on a Biogel A $15 \mathrm{~m}$ column. Samples of wort from 3 day germinated Minerva (M3) and Triumph (T3) were chromatographed and the fractions were studied (Figure 5). Minor amounts of $\beta$-glucan of molecular weight as high as $1 \times 10^{6}$ were seen. No pronounced differences were found in the molecular weight distributions of the very high molecular weight $\beta$-glucans between the worts from the two barley varieties. The amount of $\beta$-glucan from (M3) was significantly higher than for (T3).

\section{DISCUSSION}

SMITH et al. (20) suggested that the ratio between the HMW and the LMW carbohydrate fraction from acid extracts of barley flour could disclose the malting potential of a barley genotype. Our results show a similar distinction, i.e. the congress extract of the unmalted barley of the good malting variety (Triumph) consisted of aproximately equal amounts of LMW and HMW $\beta$-glucan, while the poor malting barley (Minerva) only consisted of HMW $\beta$-glucan. The amount of troublesome HMW $\beta$-glucan was significantly higher for Minerva than Triumph at all malting stages. In worts derived from Triumph germinated 5-7 days, the HMW $\beta$-glucan fraction was almost completely degraded, while the corresponding sample derived from Minerva showed a significant content of HMW $\beta$-glucans.

The elution patterns of the congress worts showed that $\beta$-glucans of molecular weights from about $2 \times 10^{3}$ to $1 \times 10^{6}$ were extracted from malts of different degrees of modification (Figures $1 \mathrm{a}, \mathrm{b}$ and 5). In a similar study, ForREST and WAINWRIGHT (12) have found $\beta$-glucan greater than $1 \times 10^{6}$ dalton in wort and BAMFORTH and MARTIN (5) have reported the presence of HMW $\beta$-glucan with a molecular weight between $4 \times 10^{4}$ and $1.5 \times 10^{7}$ besides a much greater fraction of LMW $\beta$-glucan consisting of oligosaccharides. Some of the discrepancy observed between their results and the results obtained in this investigation may be due to different extraction procedures, but different methods may also result in different estimations of molecular weights, as pointed out resently by WOODWARD and Fincher (23).

The lack of specificity of the glucose method implies a distorsion of the elution pattern due to measurement of saccharides in the low molecular weight range. Using the Calcofluor method (section 2.4) the examination is limited to the HMW $\beta$-glucan fraction with a molecular weight higher than 10,000 (Figure 4). From a brewers point of wiew, this is ideal, since the troublesome $\beta$-glucan is of high molecular weight $(5,15,17)$. The Calcofluor method has a high specificity for $\beta$-glucan $(21,22)$, and it is a rapid and simple alternative to the more laborious glucose determinations.

The results obtained indicate that other components than HMW $\beta$-glucan have a significant influence on viscosity. For example it was found that wort made from 5 day germinated Triumph had a lower viscosity $(1.75 \mathrm{cP})$, but a higher amount of HMW $\beta$-glucan (Figure Ic), than the wort made from 9 day germinated Minerva, which contained less HMW $\beta$-glucan (Figure 1d) and had a viscosity of $1.82 \mathrm{cP}$. This distinction between the HMW $\beta$-glucan content obtained from molecular fractionation of the $\beta$ glucans from (T5) and (M9) and the viscosity values are also found using the AMS- and the CEP-methods for measuring the total $\beta$-glucans in the worts (Table I). Likewise the congress worts (M0) and (M3) have almost the same content of HMW $\beta$-glucan (Figure 1b), but have viscosities of $3.30 \mathrm{cP}$ and $4.96 \mathrm{cP}$, respectively. Thus it seems, that the problem of high wort viscosity is complex, and cannot be explained by the content of HMW $\beta$-glucan alone.

\section{ACKNOWLEDGEMENTS}

The authors wish to thank Fil. Dr. LARS MUNCK for support and critical reading of the manuscript. Civilingeniør S.AA. JENSEN, Cand. Scient. S. AastruP and Dr. J. Mundy are gratefully acknowledged for stimulating discussions. We are indebted to ANNETTE HANSEN and METTE Høנ for preparing the figures. The major part of this investigation is an examination work prepared for The Department of Applied Biochemistry, Technical University of 
Denmark, Lyngby, Denmark. The support of Dr. B.B. JøRGENSEN and Professor O.B. JøRGENSEN is greatly appreciated.

\section{REFERENCES}

1. AASTRUP S.: Selection and characterization of low $\beta$-glucan mutant from barley. Carlsberg Res. Commun. 48, 307-316 (1983)

2. AASTRUP, S. \& K. ERdal: Quantitative determination of endosperm modification and its relation to the content of 1,3:1,4- $\beta$-glucans during malting of barley. Carlsberg Res. Commun. 45, 369-379 (1980)

3. Analytica-EBC, Analysis Committee of European Brewery Convention, T.M. Enari ed. SchweizerBrauerei-Rundschau, 3rd ed., Zürich, p. 87 (1975)

4. ANDERSON, M.A., J.A. COOK \& B.A. STONE: Enzymatic determination of 1,3:1,4 $\beta$-glucans in barley grains and other cereals. J. Inst. Brew. 84, 233-239 (1978)

5. BAMFORTH,C.V.\&H.L. MARTIN: The degradation of $\beta$-glucan during malting and mashing: the role of $\beta$-glucanase. J. Inst. Brew. 89, 303-307 (1983),

6. BAMFORTH, C.W.: Barley $\beta$-glucans, their role in malting and brewing. Brew. Dig. 6, 22-35 (1982)

7. BOURNE, D.T.\& J.S. PierCE: $\beta$-glucan and $\beta$-glucanase in brewing. J. Inst. Brew. 76, 328-335 (1970)

8. ERDAL, K. \& P. GJERTSEN: $\beta$-glucans in malting and brewing II. The fate of $\beta$-glucans during mashing. EBC Proc. 11th congr., 295-302 (1967)

9. ERDAL, K. \& P. GJeRTSEN: $\beta$-glucans in malting and brewing 111 . The action of endo- $\beta$-glucanases EBC Proc. 13'th congr., 49-57 (1971)

10. FinChER, G.B.: Morphology and chemical composition of barley endosperm cell walls. J. Inst. Brew. 81, 116-122 (1975)

11. ForREST, I.S. \& T. WAINWRIGHT: The mode of binding of $\beta$-glucans and pentosans in barley endosperm cell walls. J. Inst. Brew. 83, 279-286 (1977)

12. ForRest, I.S. \& T. WAINWRIGHT: Differentiation between desirable and troublesome $\beta$-glucans. EBC Congress 1977, 401-412.

13. GJERTSEN, P.: $\beta$-glucans in malting and brewing. I. Influence of $\beta$-glucans on the filtration of strong beer. ASBC. Proc., 113-120 (1966)

14. GJERTSEN, P.: Filtration of beer and factors influencing its filterability. Brew. Dig. 9, 68-80 (1970)

15. JENSEN, S.A. \& S. AASTRUP: A fluorimetric method for measuring 1,3:1,4- $\beta$-glucans in beer, wort, malt and barley by use of Calcofluor. Carlsberg Res. Commun. 46, 87-95 (1981)

16. JøRGENSEN, K.G.: An improved method for determining $\beta$-glucan in wort and beer by use of $\mathrm{Cal}$ cofluor. Carlsberg Res. Commun 48, 505-516 (1983)

17. MUnCK. L., G. GibBons \& S. AAStRup: Chemical and structural changes during malting. EBC Congress 1981, 11-30

18. Preece, I.A. \& K.G. MaCKenziE: Non-starchy polysaccharides of cereal grains. I. Fractionation of the barley gums. J. Inst. Brew. 58, 353-362 (1952)

19. SCOTt, R.W.: The viscosity of wort in relation to their contents of $\beta$-glucans. J. Inst. Brew. 78, 179-186 (1972)

20. SMITH, D.B., A.G. MORGaN \& S. AASTRUP: Variation in the biochemical composition of acid extracts from barleys of contrasting malting quality. J. Inst. Brew. 86, 277-283 (1980)

21. WoOD, P.J.: Specificity in the interaction of direct dyes with polysaccharides. Carbohydr. Res. 94, 271-287 (1980)

22. WOOD, P.J., R.G. FULCHER \& B.A. STONE: Studies on the specificity on the interaction of cereal cell wall components with Congored and Calcofluor. Specific detection and histochemistry of $(1 \rightarrow 3),(1 \rightarrow 4)$, $-\beta-D-$ glucan. J. Cereal Science 1 , 95-110 (1983)

23. WOODWARD J.R. \& G.B. FinCHER: Water soluble barley $\beta$-glucans, fine structure, solution behavior and organization in the cell wall. Brew. Digest., 28-32 (1983) 